\title{
Reef structure regulates small-scale spatial variation in coral bleaching
}

\author{
Hunter S. Lenihan ${ }^{1, *}$, Mehdi Adjeroud ${ }^{2,3}{ }^{\text {, Matthew J. Kotchen }}{ }^{1}$, James L. Hench ${ }^{4}$, \\ Takashi Nakamura ${ }^{5}$
}

\author{
${ }^{1}$ Bren School of Environmental Science and Management, University of California, Santa Barbara, California 93106-5131, USA \\ ${ }^{2}$ Centre de Biologie et d'Ecologie Tropicale et Mediterranéenne, Ecole Pratique des Hautes Etudes, \\ UMR 5244 CNRS-EPHE-UPVD, Université de Perpignan, 66860 Perpignan Cedex, France \\ ${ }^{3}$ Centre de Recherches Insulaires et Observatoire de l'Environnement, UMS 2978 CNRS-EPHE, Papetoai, BP 1013 Moorea, \\ French Polynesia \\ ${ }^{4}$ Environmental Fluid Mechanics Laboratory, Stanford University, Yang \& Yamazaki Building, 473 Via Ortega, Stanford, \\ California 94305-4020, USA
}

${ }^{5}$ AMBL, Kyushu University, Kumamoto 863-2507, Japan

\begin{abstract}
Coral bleaching is often characterized by high spatial variation across reef systems. Using a field survey and manipulative experiment, we tested whether the physical structure of coral reefs modifies environmental conditions that, in turn, influence spatial variation in bleaching in 3 scleractinian corals, Pocillopora verrucosa, Acropora elseyi, and Porites rus. Corals inhabit mainly the hard-bottom seafloor, or dead or partially dead coral heads ('bommies'). Bommies (0.10 to $3.0 \mathrm{~m}$ tall) position corals at different water depths and expose them to differences in light, temperature, hydrodynamics, and sedimentation, factors that can influence patterns of bleaching. We conducted our study in association with a $14 \mathrm{~d}$ warming event that caused bleaching in lagoons of Moorea, French Polynesia. Bleaching in naturally occurring colonies of Pocillopora spp. and Acopora spp. was greater on the seafloor ( $0 \mathrm{~m}$ tall) than on short ( 0.35 to $0.40 \mathrm{~m}$ tall) and tall bommies (1.0 to $1.2 \mathrm{~m}$ tall). Bleaching in $P$. verrucosa and $A$. elseyi transplanted to reef structures in the experiment generally decreased with increasing reef height (seafloor $>$ short bommies $>$ tall bommies). P. rus did not bleach under any conditions observed. Regression analyses revealed that reef structure controlled current speed and sedimentation at the microhabitat scale (from centimeters to meters), and that these factors regulated bleaching and mortality in $P$. verrucosa and $A$. elseyi. Our results imply that the physical structure of shallow water reef habitat influences the performance of coral colonies by modifying environmental stress, and that accounting for this structure is important in managing coral reef systems.
\end{abstract}

KEY WORDS: Bleaching · Coral - Environmental stress $\cdot$ Hydrodynamics $\cdot$ Habitat structure $\cdot$ Light $\cdot$ Sedimentation · Temperature

\section{INTRODUCTION}

The physical structure of habitats can regulate the distribution and abundance of organisms by influencing ecological processes, including recruitment (Underwood \& Denley 1984), competition (MacArthur \& MacArthur 1961), predation (Huffacker 1958), and dis- turbance (Dayton 1971). In aquatic ecosystems, the physical characteristics of habitat also influence population and community dynamics by modifying environmental conditions that have subsequent effects on individual organisms (Genin et al. 1986, Lenihan 1999). Here we report results of a study designed to test whether coral reef habitat modifies environmental 
conditions, thereby reducing environmental stress and regulating coral performance.

Decline in coral populations and associated degradation of reef communities are being reported worldwide with increasing frequency (Hughes et al. 2003). Natural catastrophes, including storms, predator outbreaks, and disease, kill corals and damage reefs (Connell et al. 1997, Hughes et al. 2003), as do many anthropogenic disturbances (Hughes 1994, Jackson et al. 2001, Fox \& Caldwell 2006). Coral bleaching is both a natural and human-induced phenomenon that causes complex spatial heterogeneity in coral mortality and resulting changes in coral community composition (Lang et al. 1988, Glynn 1996, Brown et al. 2002, Coles \& Brown 2003). Corals bleach when they lose symbiotic dinoflagellate algae (zooxanthellae), or when symbionts lose photosynthetic pigment. Without energy from symbiont photosynthesis, primary production is reduced and coral mortality increases (Glynn 1993). Corals bleach in response to many environmental stressors (Brown 1997), but a common cause appears to be the combined effect of elevated water temperature and high light intensity (Lesser et al. 1990, Fitt \& Warner 1995).

Spatial heterogeneity in coral bleaching from local (from meters to kilometers) to regional (100 to $1000 \mathrm{~km}$ ) scales is a common but perplexing feature of bleaching events (Hoegh-Guldberg \& Salvat 1995, Berkelmans \& Oliver 1999). Understanding mechanisms that cause this heterogeneity has proven difficult because many biological, ecological, and environmental factors may be involved and are difficult to isolate (Glynn 1993). Bleaching prevalence and intensity usually increase with water temperature and the duration of the temperature anomaly (Berkelmans 2002, McWilliams et al. 2005). However, a wide variety of other environmental factors also appears to influence intraspecific differences in bleaching (Gleason 1993, Jokiel et al. 1997, Berkelmans et al. 2004, Obura 2005), including exposure to extreme tides and desiccation (Anthony \& Kerswell 2007), shading (Mumby et al. 2001), wave exposure (Anthony \& Kerswell 2007), and history of disturbances impacting individual coral colonies (Kinzie et al. 2001, Brown et al. 2002, Baker et al. 2004, Sotka \& Thacker 2005). For example, bleaching declines through serial warming events when coral assemblages and/or their zooxanthellae acquire phenotypic (acclimation) and/or genotypic (adaptation) resistance to thermal stress (Rowan et al. 1997, Hoegh-Guldberg 1999, Adjeroud et al. 2002). Several studies also indicate that water motion can mitigate bleaching and increase recovery (Nakamura \& van Woesik 2001, Nakamura \& Yamasaki 2005, Nakamura et al. 2005, Fabricius 2006, Anthony et al. 2007). However, substantial debate surrounds this issue
(McClanahan et al. 2005b, van Woesik et al. 2005), as other studies indicate that flow can intensify bleaching (e.g. McClanahan et al. 2005a).

Our previous observations of macroscale $(100 \mathrm{~m}$ to $1 \mathrm{~km}$ ) patterns in bleaching events in French Polynesia (Penin et al. 2007) included a qualitative assessment that bleaching also varied with the microscale (from centimeters to meters) structure of reefs. Here we report the results of (1) a quantitative survey that examined whether coral bleaching varies as a function of physical reef structure and (2) a manipulative field experiment designed to test whether reefs modify local environmental conditions (current speed, temperature, light, and sedimentation) that, in turn, regulate bleaching in 3 scleractinian corals, Pocillopora verrucosa (Pocilloporidae), Acropora elseyi (Acroporidae), and Porites rus (Poritidae).

\section{MATERIALS AND METHODS}

Study site. We conducted our survey and experiment during austral winter 2003 at 2 sites located in the lagoon on the north shore of Moorea $\left(17^{\circ} 30^{\prime} \mathrm{S}\right.$, $149^{\circ} 50^{\prime} \mathrm{W}$ ), an island located $19 \mathrm{~km}$ west of Tahiti in French Polynesia (Fig. 1). Moorea has several relatively deep (10 to $35 \mathrm{~m}$ ) bays, and is encircled by a barrier reef that forms shallow (2 to $4 \mathrm{~m}$ water depth) lagoons. The first site, Cook's Crest, is patch reef habitat (3 m depth) located $\sim 200 \mathrm{~m}$ inside of the barrier reef. Gump Reef, the second site, is a fringing reef (1.5 to $6 \mathrm{~m}$ depth) located near the mouth of Cook's Bay. The seafloor at both sites is a mosaic of substrate types (coral rubble, sand, and limestone bottom) interspersed with coral colonies ranging in diameter from a few millimeters to $>3 \mathrm{~m}$. The largest coral heads are created by Porites rus, P. lobata, $P$. australiensis, and

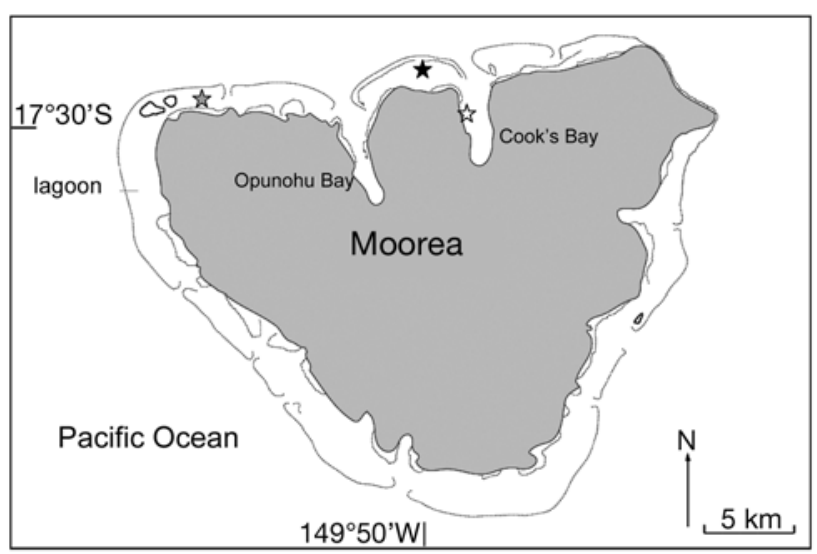

Fig. 1. Study sites on the north shore of Moorea, French Polynesia. $\star$ : location of Tiahura temperature gauge; $\star$ : Cook's Crest site; is: Gump Reef site 
P. lutea. Dead or partially dead Porites colonies (i.e. coral 'bommies') are colonized by a diversity of organisms and other corals, mainly Pocillopora, Acropora, Montipora, and Fungia (Adjeroud 1997). Acropora elseyi, Pocillopora verrucosa, and Porites rus are common corals in lagoons of Moorea, where they provide habitat utilized by a high diversity of coral reef fishes (Holbrook et al. 2002). Pocillopora verrucosa and Porites rus are abundant, and live coral cover is relatively high ( $\geq 67 \%$ ) at both study sites (Holbrook et al. 2002). A. elseyi is common at Cook's Crest, but like most acroporid corals is not abundant at Gump Reef. Nevertheless, Gump Reef can sustain Acropora species, as 45 colonies of $A$. elseyi have persisted there for $5 \mathrm{yr}$ since being transplanted in 2002 (H. Lenihan unpubl. data).

Coral reefs in Moorea have been impacted over the past several decades by a series of natural disturbances, including outbreaks of crown-of-thorns starfish Acanthaster planci (1980, 1982, and 1984), cyclones (1982/1983 and 1991), and major coral bleaching events (1984, 1987, 1991, 1994, and 2002) (Gleason 1993, Adjeroud et al. 2002, 2005, Penin et al. 2007). In addition, the human population of the island continues to expand, leading to increased levels of subsistence fishing and intensive coastal development adding sediment, nutrient, and pollutant inputs to lagoons. Coincident in time with these natural disturbances and increases in human activities is a reported shift in coral reef community composition characterized by a decline in the abundance of Acropora spp. and an increase in the relative abundance of Pocillopora spp. and Porites spp. (Done et al. 1991, Adjeroud 1997, Berumen \& Pratchett 2006).

Survey of bleaching in natural coral populations. On 19 August 2003, we surveyed populations of naturally occurring adult Acropora spp., Pocillopora spp., and Porites rus corals located at Cook's Crest and Gump Reef to determine patterns of bleaching. This date was $7 \mathrm{~d}$ after the end of a $14 \mathrm{~d}$ warming event (Table 1), a period characterized by intense sunlight (i.e. cloudless skies) and a lack of wind, swell, and waves. This combination of environmental factors led to reduced circulation and increased water temperatures within the lagoons of Moorea associated in time and space with a moderate level of coral bleaching

Table 1. Timeline of the bleaching event, field surveys, experiments, and sampling of environmental conditions (Temp: temperature) conducted in the present study. Letters in parentheses refer to manipulations illustrated in Fig. 2. X: sampled. Shaded area denotes period of warming event

\begin{tabular}{|c|c|c|c|c|c|c|c|c|}
\hline \multirow[t]{2}{*}{ Year } & \multirow[t]{2}{*}{ Date } & \multirow[b]{2}{*}{ Survey } & \multicolumn{2}{|c|}{ Coral experiments } & \multicolumn{4}{|c|}{ Environment sampling } \\
\hline & & & Transplant & Control & Temp. & Current & $\begin{array}{l}\text { Sediment } \\
\text { deposition }\end{array}$ & Light \\
\hline 2002 & $26 \mathrm{Nov}$ & & & $\begin{array}{l}\text { Collected corals at Cook's } \\
\text { Crest (I, J). Transplanted } \\
\text { to Gump Reef }(\mathrm{M}, \mathrm{N})\end{array}$ & & & & \\
\hline \multirow[t]{17}{*}{2003} & 9 Jun & & & $\begin{array}{l}\text { One half of corals trans- } \\
\text { planted from Gump } \\
\text { Reef to Cook's Crest }(K, L)\end{array}$ & & & & \\
\hline & 27 Jun & & $\begin{array}{l}\text { Collected corals at } \\
\text { Cook's Crest (A, B). } \\
\text { Corals placed in } \\
\text { Gump Lab aquaria }\end{array}$ & & & & & \\
\hline & $30 \mathrm{Jun}$ & & $\begin{array}{l}\text { Transplanted to experi- } \\
\text { mental reefs at Cook's } \\
\text { Crest and Gump Reef }(\mathrm{C}-\mathrm{H})\end{array}$ & & & & & \\
\hline & $5 \mathrm{Jul}$ & & & & & $\mathrm{X}$ & & \\
\hline & 9 Jul & & $\mathrm{X}$ & & & & & \\
\hline & $15 \mathrm{Jul}$ & & $\mathrm{X}$ & & $\mathrm{X}$ & & $\mathrm{X}$ & \\
\hline & $20 \mathrm{Jul}$ & & $\mathrm{X}$ & & $\mathrm{X}$ & & $\mathrm{X}$ & \\
\hline & $28 \mathrm{Jul}$ & & & & & & $\mathrm{X}$ & \\
\hline & $29 \mathrm{Jul}$ & & $\mathrm{X}$ & & $\mathrm{X}$ & & $\mathrm{X}$ & \\
\hline & $31 \mathrm{Jul}$ & & & & & $\mathrm{X}$ & $\mathrm{X}$ & \\
\hline & 6 Aug & & $\mathrm{X}$ & & $\mathrm{X}$ & & $\mathrm{X}$ & \\
\hline & $12 \mathrm{Aug}$ & & $\mathrm{X}$ & & $\mathrm{X}$ & & $\mathrm{X}$ & \\
\hline & 19 Aug & $\mathrm{X}$ & & & & & & \\
\hline & $20 \mathrm{Aug}$ & & $\mathrm{X}$ & $\mathrm{X}$ & $\mathrm{X}$ & $\mathrm{X}$ & & \\
\hline & $21 \mathrm{Aug}$ & & & & & & & \\
\hline & $18 \mathrm{Nov}$ & & $\mathrm{X}$ & & $\mathrm{X}$ & & & \\
\hline & $19 \mathrm{Nov}$ & & $\mathrm{X}$ & & & & & \\
\hline 2005 & $13 \mathrm{Aug}$ & & & & & & & $\mathrm{X}$ \\
\hline
\end{tabular}


around the island (Penin et al. 2007). To sample natural coral colonies, we haphazardly placed four $20 \mathrm{~m}$ transect lines at each site and counted the number of coral colonies with bleaching on the seafloor, short bommies ( 0.1 to $0.5 \mathrm{~m}$ tall), and tall bommies ( $>0.75 \mathrm{~m}$ tall). The sizes of 'short' and 'tall' bommies varied somewhat between those in the survey and experiment (see next subsection). Tissue that had lost all pigment was considered bleached, and only coral colonies with at least $25 \%$ of their total surface areas with pigment loss were considered bleached. We compared patterns of bleaching in this survey with patterns in our manipulative experiment to gauge the generality of our experimental results.

Experimental reefs and coral transplants. To test the effects of reef structure on coral bleaching, we used 3 common substrata, the pavement seafloor and 2 coral bommie types (short: 0.35 to $0.40 \mathrm{~m}$ in height; tall: 1.0 to $1.2 \mathrm{~m} ; \mathrm{n}=20$ per substratum per site), to expose coral colonies to different environmental conditions, specifically temperature, light, current speed, and sedimentation. Bommies were composed of dead Porites lobata coral heads located in 2.0 to $2.25 \mathrm{~m}$ depth. We refer to the different substrata ('reef structures') as the seafloor, short bommies, and tall bommies.

On 27 June 2003, corals were collected from Cook's Crest, transported to aquaria at Richard Gump Research Station located in Cook's Bay, and then transplanted 3 d later to Cook's Crest and Gump Reef (Fig. 2, Table 1). We harvested 150 small (8 to $9 \mathrm{~cm}$ in diameter) colonies of Pocillopora verrucosa from the limestone seafloor. For Acropora elseyi and Porites rus, we harvested 150 replicate fragments (10 to $20 \mathrm{~cm}$ tall pieces, each with 2 distinct branches) from 3 large colonies of each species located on short $(30 \mathrm{~cm}$ tall) bommies. After 3 d in aquaria, 120 healthy looking individuals of each species were transplanted to the seafloor, short bommies, and tall bommies at Gump Reef and Cook's Crest using non-toxic Z-spar ${ }^{\mathrm{TM}}$ marine adhesive. Corals were deployed for 28 d (30 June to 28 July 2003) at Cook's Crest and Gump Reef before the bleaching event (Table 1).

We report results from an unplanned bleaching event, and therefore did not employ a complete reciprocal transplant experiment in which corals endemic to each site $\times$ treatment combination were transplanted to all other treatment combinations (i.e. 36 possible transplant combinations). A complete reciprocal transplant design is optimal because it provides a test of whether and to what degree bleaching occurs because corals or their zooxanthellae are, or are not, acclimated to environmental conditions at a given site (McClanahan et al. 2005b). However, the length of time it takes for transplanted corals and/or their zooxanthellae to acclimate to a new site is not well understood, and several studies indicate acclimation is possible within only a few weeks (e.g.

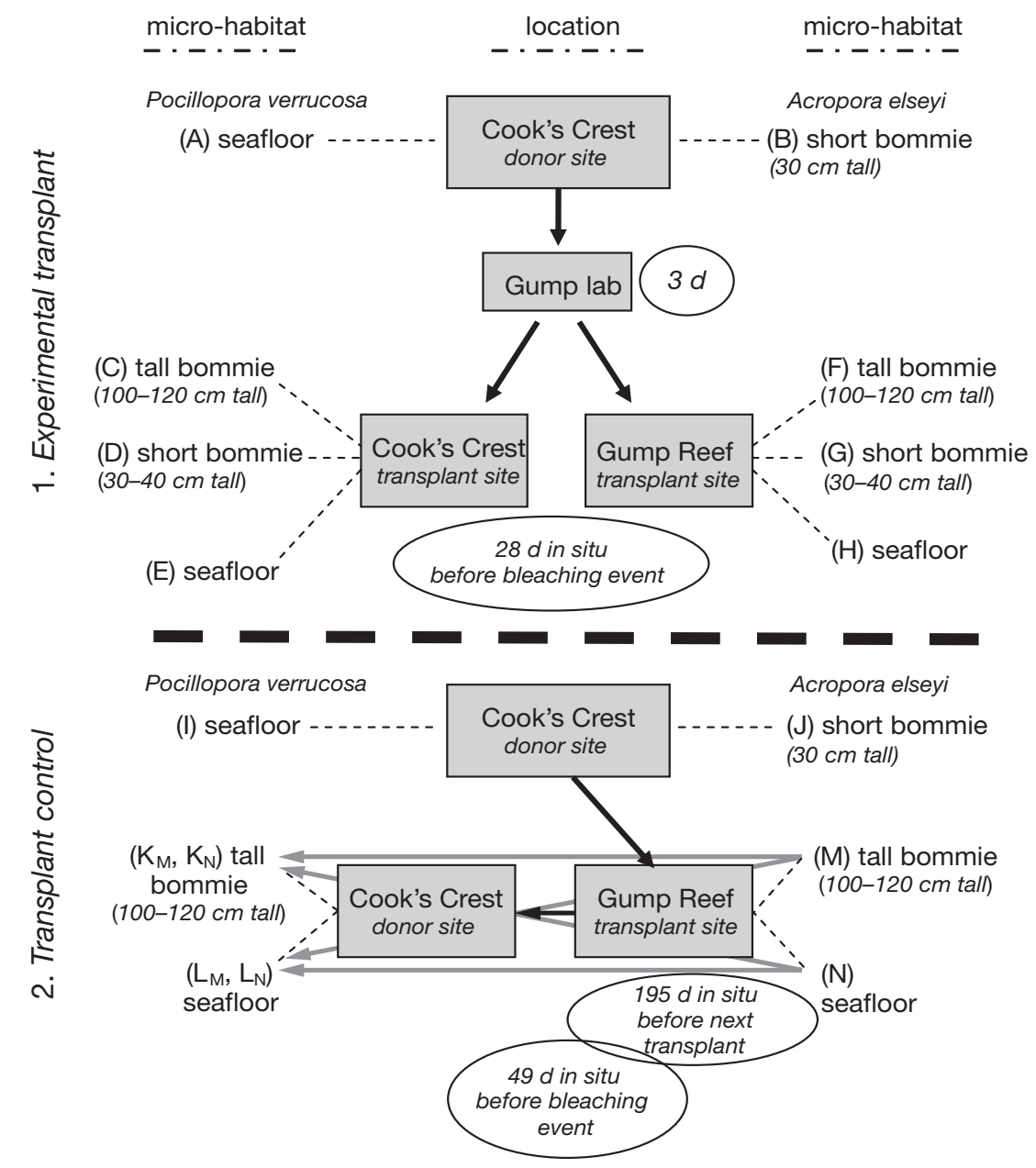

Fig. 2. Diagram illustrating the transplantation process for colonies of Pocillopora verrucosa and Acropora elseyi corals in the manipulative experiment (1) and transplant control experiment (2). Another species, Porites rus, was also transplanted (in the same manner as A. elseyi), but displayed no bleaching during the present study. All corals originated from coral groups A, B, I, and J, and corals that remained at these locations were included, along with transplanted corals A to $\mathrm{N}$, in the statistical comparisons presented in Tables A1 \& A2 (available at http://www.int-res.com/journals/suppl/m370p127_app.pdf), which were designed to test whether patterns of bleaching resulted from poor acclimation to a site or habitat type. Results showed all corals were sufficiently acclimated. Gray lines indicate that both species in $\mathrm{M}$ and $\mathrm{N}$ were transplanted to the same habitats and to different habitats ( $\mathrm{K}$ and $\mathrm{L}$ ) 
Lesser et al. 1994, Anthony \& Hoegh-Guldberg 2003, van Woesik et al. 2005). Results presented below indicate that the corals we transplanted did not display any evidence of poor acclimation.

Data from a concurrent experiment conducted at the same sites provides additional evidence that the corals we transplanted were adequately acclimated before the bleaching event. In November 2002, we collected small colonies of Pocillopora verrucosa $(\mathrm{n}=36)$ and fragments of Acropora elseyi $(\mathrm{n}=32)$ from the same places at Cook's Crest from which we eventually collected corals in June 2003 (Fig. 2). These colonies and fragments were transplanted to the seafloor and tall bommies at Gump Reef, also using Z-spar. On 9 June 2003, half of the corals of both species were transplanted back to the seafloor or to tall bommies at Cook's Crest (Table 1). The remaining half of the corals stayed on the seafloor and tall bommies at Gump Reef. As a consequence, all corals spent 195 d (26 November 2002 to 9 June 2003) at Gump Reef, and then spent another 49 d (9 June to 28 July 2003) at both sites before being exposed to the bleaching event. Differences in the rate of bleaching between these 'Transplant controls' and those in the main experiment ('Experimental transplants') provide an estimate of how well corals were acclimated to environmental conditions at each site. Results of this comparison indicate that transplanted corals did not exhibit evidence of poor acclimation.

Bleaching and mortality in experimental corals. We estimated the percent of bleached or dead tissue for each coral colony in our experiment on 9 July 2003, 9 d after they were transplanted, and $30 \mathrm{~d}$ after transplanting the reciprocal controls (Table 1). We then measured change in percentage of tissue bleached and dead every 5 to $10 \mathrm{~d}$ in the experimental corals from 9 July until 20/21 August. Tissue mortality among these corals was measured again on 18/19 November. Bleaching and mortality were examined in reciprocal control corals on 20 August 2003 (Table 1).

Estimates of tissue bleaching (i.e. pigment loss) and mortality of corals were made visually in $10 \%$ increments for each individual colony. Tissue was considered dead if it had lost pigment, turned a grayish color, and was covered by sediment or algae. We tested the accuracy of our visual estimating technique by comparing field estimates (i.e. those taken from partially bleached and morbid corals that were left in the aquaria after the transplant procedure) with those taken directly from the same corals in the laboratory using fine mesh squares of known dimensions. Our field estimates had a mean error of $<5 \%$, which we judged to be sufficiently precise.

Environmental conditions. Water temperature was recorded with a hand-held thermometer on 10 ran- domly selected reef structures of each type (i.e. seafloor, short bommie, and tall bommie) on 15 July, and then every 5 to $10 \mathrm{~d}$ beginning 29 July 2003, the date on which we noticed evidence of a warming event (Table 1). Water temperature was also measured continuously, at a sampling rate of 1 sample $\mathrm{min}^{-1}$, with a Hobotemp temperature logger placed at $2.5 \mathrm{~m}$ water depth at Tiahura (Fig. 1), a site located $150 \mathrm{~m}$ inside of the barrier reef near Taotoi Pass, which is $\sim 5.5 \mathrm{~km}$ west of Cook's Crest.

Current speed and direction were measured on reef structures because they influence coral performance (Thomas \& Atkinson 1997, Sebens et al. 1998, 2003). We made the following predictions about current speed in our experiment: (1) it is greater over tall bommies than over short bommies and the seafloor because it increases with distance above the bottom in a typical frictional boundary layer and (2) it is greater over tall bommies than short bommies because it is forced to move through a smaller volume and fluid mass must be conserved (Lenihan 1999). To test these predictions, we measured horizontal current speed, defined as $\sqrt{U^{2}+V^{2}}$, where $U$ and $V$ are the east-west and north-south velocity components, respectively (the sign convention is east and north are positive), on the top portions of 10 randomly selected reef structures of each type at each site on 5 July (before the warming event), 31 July (during the warming event), and 21 August (after the bleaching event) with an acoustic doppler velocimeter (ADV; $6 \mathrm{MHz}$ Nortek Vector) that was placed sequentially on each reef for an averaging period of $10 \mathrm{~min}$ (Table 1).

Sedimentation can reduce coral performance (Rogers 1990, Mills \& Sebens 2004), but, in contrast, it can also decrease mortality associated with bleaching (Anthony et al. 2007). Sediment deposition declines on reef bommies with distance above the seafloor because the primary sediment input is from material resuspended from the seafloor (Yahel et al. 2002). Consequently, we predicted that sediment deposition on reef structures would decrease with increasing reef height (seafloor $>$ short bommie $>$ tall bommie). To test this prediction, sedimentation was measured using sediment traps placed on reef structures during the period from 15 July to 6 August (Table 1). Traps consisted of Astroturf mats (36 $\mathrm{cm}^{2}$ in area; $2 \mathrm{~cm}$ thick) placed within square plastic trays, the sides of which were trimmed so that they were flush with the top of the Astroturf blades. One sediment trap was placed on each of 10 randomly selected reef structures at each site. Sediment traps were collected by divers after $21 \mathrm{~d}$ of exposure, were gently placed in Ziplock bags underwater, and then frozen. Samples were dried in an oven at $75^{\circ} \mathrm{C}$ for $24 \mathrm{~h}$ and weighed on a top-loading microbalance. Our measure of sedimentation is proba- 
bly an underestimation of the actual amount because we did not measure the organic content of material that accumulated in sediment traps.

Light level was measured across our 2 study sites to test whether variation in solar irradiance explained variation in bleaching among reef structures. We report light measurements made in August 2005 (Table 1) as a proxy for the light during the experiment in 2003. These data provide a meaningful proxy for light conditions during our experiment for 2 reasons. First, we made many light measurements before and after our experiment and saw very little change through time in light profiles at Gump Reef and Cook's Crest when season, hour of the day, atmospheric conditions, and water clarity are held relatively constant. Second, we measured light at Cook's Crest and Gump Reef in August 2005 under conditions of atmospheric and water clarity and temperature that appeared be the same as those present during the warming event in July and August 2003. Light intensity $\left(\mu \mathrm{mol} \mathrm{s}^{-1} \mathrm{~m}^{-2}\right)$ was recorded on 13 August 2005 at a distance of 3 to $6 \mathrm{~m}$ away from our reef structures with a Li-COR, LI-1400 data logger. Three replicate profiles were taken at each site between 11:30 and 13:00 h. We report light measurements as the combined value of both spherical and directional light, the maximum range of which in tropical lagoons is about 1000 to $4500 \mu \mathrm{mol} \mathrm{s}^{-1} \mathrm{~m}^{-2}$.

Statistical approach. Our first objective was to determine whether the warming event observed in Moorea in July and August 2003 increased water temperatures in our experiment. Our approach was to compare mean water temperatures measured on reef structures in a 3-way ANOVA in which site (Cook's Crest vs. Gump Reef), period (before, during, and after the warming event), and reef structure (seafloor vs. short bommies vs. tall bommies) were crossed, fixed factors. For all ANOVAs, variances were compared with Cochran's test, and when heterogeneous, were transformed using the appropriate formula.

Our second objective was to test whether naturally occurring Pocillopora spp., Acropora spp., and Porites spp. colonies, located at Cook's Crest and Gump Reef, and sampled on 19 August, bleached in relation to the warming event, and whether bleaching varied as a function of taxon (i.e. genus), site, and reef structure. We did this by comparing the pattern of bleaching (i.e. total proportion of coral colonies that bleached $\geq 25 \%$ of their surface area) on 19 August 2003 in adult corals located on the seafloor, short bommies, and tall bommies in a 3-way ANOVA in which the 3 genera, site (Cook's Crest vs. Gump Reef), and reef structure were crossed, fixed factors. Reef structure sampled here was different from that used in the transplant and transplant control experiments.
Our third objective was to use multiple regression models to test whether bleaching in Pocillopora verrucosa and Acropora elseyi varied across reef structures in the transplant experiment and, simultaneously, to identify whether the pattern of bleaching was related to differences in water temperature, light intensity, sediment deposition, and current speed. Porites rus did not bleach during our experiment so it was not included in our analyses. For $P$. verrucosa and A. elseyi, we first estimated models of the form:

$$
Y_{i}=\tau+\boldsymbol{\beta} \mathbf{X}_{i}+\gamma \text { Short }_{i}+\rho \operatorname{Tall}_{i}+\delta \text { Cooks }_{i}+\varepsilon_{i}
$$

where $Y_{i}$ is the percent of bleached coral at sample site $i_{i} \tau$ is the intercept; $\mathbf{X}_{i}$ is a column vector of the environmental variables (temperature, light, sedimentation, and current speed); Short ${ }_{i}$ is a dummy variable for the short bommies; Tall $_{i}$ is a dummy variable for tall

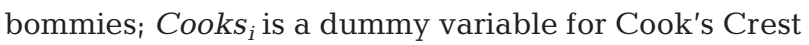
site; and $\varepsilon_{i}$ is the error term.

The coefficients of primary interest are those in the row vector $\boldsymbol{\beta}$. These coefficients provide estimates of the effect that each environmental variable had on the rate of bleaching, while controlling for average differences in bleaching between reef treatments and sites. Temperature measurements used were those recorded across experimental reefs during the warming event; current speeds were the means of measurements made before and after the warming event, as there was almost no detectable current during the event; and sedimentation rates were recorded from 15 July to $16 \mathrm{Au}$ gust (before and during the warming event). Light measured in August 2005 was used as a proxy for light measured in August 2003 (see above). The estimates of $\gamma$ and $\rho$ account for average differences in the bleaching rate between the seafloor (the omitted category) and the short and tall bommies, respectively. The difference in bleaching between short and tall bommies is the difference between $\gamma$ and $\rho$. The coefficient $\delta$ accounts for differences in the bleaching rate between Cook's Crest and Gump Reef that are not explained by either the environmental variables or reef treatments.

Specification (1) uses all of the data to identify the effect of environmental conditions on the extent of bleaching, while accounting for unobserved heterogeneity due to reef treatment (i.e. seafloor, short and tall bommies) and sample size. A limitation of the specification is the assumption that the relationship between environmental conditions and bleaching was constant across reef treatments. In the experiment, however, this need not be the case, for, as we predicted, changes in temperature, light, sedimentation, and current speed might have affected bleaching differently across reef treatments. We tested for such differences with a less restrictive and therefore more general specification of the form: 


$$
\begin{aligned}
Y_{i}= & \tau+\boldsymbol{\beta} \mathbf{X}_{i}+\boldsymbol{\varphi} \mathbf{X}_{i}+\text { Short }_{i}+\phi \mathbf{X}_{i}+\text { Tall }_{i}+ \\
& \gamma_{\text {Short }_{i}}+\rho \text { Tall }_{i}+\delta \text { Cooks }_{i}+\varepsilon_{i}
\end{aligned}
$$

This specification differs because it includes interaction terms between the environmental conditions and reef treatments. Again, seafloor is the omitted category, which is necessary to avoid perfect colinearity, against which we estimate the effects of short and tall bommies. The useful implication is that Specification (2) identifies the effects of environmental conditions on bleaching rates that differ between reef treatments, while still controlling for average differences in bleaching between reef treatments and sites. Specifically, the effects of environmental conditions on the rate of bleaching for each reef treatment correspond as follows: $\beta$ for the seafloor, $\beta+\varphi$ for short bommies, and $\beta+\phi$ for tall bommies. Differences between these linear combinations, as we show in the next section, can also be used to determine whether differences in the effects of environmental conditions between reef treatments were statistically significant.

Our final objectives were (1) to examine differences in the level and spatial pattern of bleaching in transplanted and naturally occurring corals, as a means of measuring the generality of our experimental results, and (2) to test whether patterns of bleaching in the experimental corals were consistent with the predicted treatment effects, or conversely, whether they exhibited evidence of poor acclimation that would bias our results. The first test was performed with a 1-way ANOVA, and the second test with a series of paired $t$-tests.

\section{RESULTS}

\section{Sea surface warming event}

From 28 July to 12 August 2003, mean water temperature in lagoons on the north shore of Moorea increased to $1.3-2.4^{\circ} \mathrm{C}$ above ambient levels recorded in austral winter 2003. The continuous temperature monitoring at Tiahura recorded temperatures of 27.5 to $29.0^{\circ} \mathrm{C}$, which included diurnal variation of $\leq 1.7^{\circ} \mathrm{C}$. Similar but longer periods of reduced circulation coupled with high solar radiation have been linked to major bleaching events in Moorea (Gleason 1993, Penin et al. 2007). Temperatures across all experimental reef structures increased during this period as well (Table 2). Mean ( $\pm 1 \mathrm{SD})$ daylight temperature was $26.3 \pm 0.5^{\circ} \mathrm{C}$ 'before', $28.8 \pm 0.4^{\circ} \mathrm{C}$ 'during', and $26.5 \pm$ $0.3^{\circ} \mathrm{C}$ 'after' the warming event. Water temperature measured on reef structures varied as a function of period (3-way ANOVA, degrees of freedom = 2,168; mean square $=104.05, F=1337.23, \mathrm{p}<0.0001)$, but did not vary with site (Cook's Crest vs. Gump Reef; SNK
Table 2. Mean water temperatures measured on reef structures in 2003. Temperature was measured at midday on 10 replicate reefs per site. Temperatures in grey area: those measured during a period of reduced water circulation ('warming event') associated with coral bleaching; NA: not applicable

\begin{tabular}{|l|c|c|c|}
\hline \multirow{2}{*}{ Date } & \multicolumn{2}{|c|}{ Bommies } & \multirow{2}{*}{ Seafloor } \\
& Tall & Short & \\
\hline 9 Jul & NA & NA & NA \\
\hline $15 \mathrm{Jul}$ & 27.5 & 26.8 & 26.5 \\
\hline $22 \mathrm{Jul}$ & 27.0 & NA & NA \\
\hline $29 \mathrm{Jul}$ & 28.6 & 28.7 & 28.4 \\
\hline 6 Aug & 28.8 & 28.8 & 28.4 \\
\hline $12 \mathrm{Aug}$ & 28.6 & 28.7 & 28.5 \\
\hline $20 \mathrm{Aug}$ & 26.3 & 26.3 & 26.2 \\
\hline $18 \mathrm{Nov}$ & 26.9 & 26.9 & 26.8 \\
\hline
\end{tabular}

[Student-Newman-Keuls test]: $\mathrm{p}>0.05$ ) or reef structure (seafloor vs. short bommies vs. tall bommies; SNK: $\mathrm{p}>0.05)$. Temperature was significantly higher during the warming event than before or after the event (SNKs: $\mathrm{p}<0.05$ ), but did not differ between the before and after periods (SNK: $\mathrm{p}>0.05$ ).

\section{Bleaching in natural corals}

On 19 August 2003, $7 \mathrm{~d}$ after the warming event, 4 to $24 \%$ of the total number of naturally occurring Pocillopora spp. and Acropora spp. coral colonies located at Cook's Crest and Gump Reef were bleached (Fig. 3). Bleaching among the corals varied as a function of taxa and reef structure (3-way ANOVA; $_{\text {; }}$ reef structure $\times$ genera interaction; $\mathrm{df}=2,47$; mean square $=122.50$; $F=4.92 ; \mathrm{p}=0.013$ ). For both genera, a greater proportion of corals bleached on the seafloor than on short and tall bommies (SNK: $\mathrm{p}<0.05$ ), and, although there was a trend towards greater bleaching on short bommies than tall bommies, there was no significant difference between these treatments (SNK: $p>0.05$ ). Interaction in the ANOVA occurred because bleaching was greater in Acropora spp. than Pocillopora spp. on short and tall bommies only (SNK: $\mathrm{p}<0.05$ ). Porites spp. did not bleach in any treatment.

\section{Effects of reef structure and environmental conditions}

Pocillopora verrucosa and Acropora elseyi transplants in the experiment exhibited a minor amount of bleaching $(\leq 5 \%$; Fig. 4$)$ and mortality $(<10 \%$; Fig. 5$)$ from 9 to 29 July 2003, prior to the warming event. Bleaching in both species increased substantially on 6 August when water temperature increased. Descrip- 


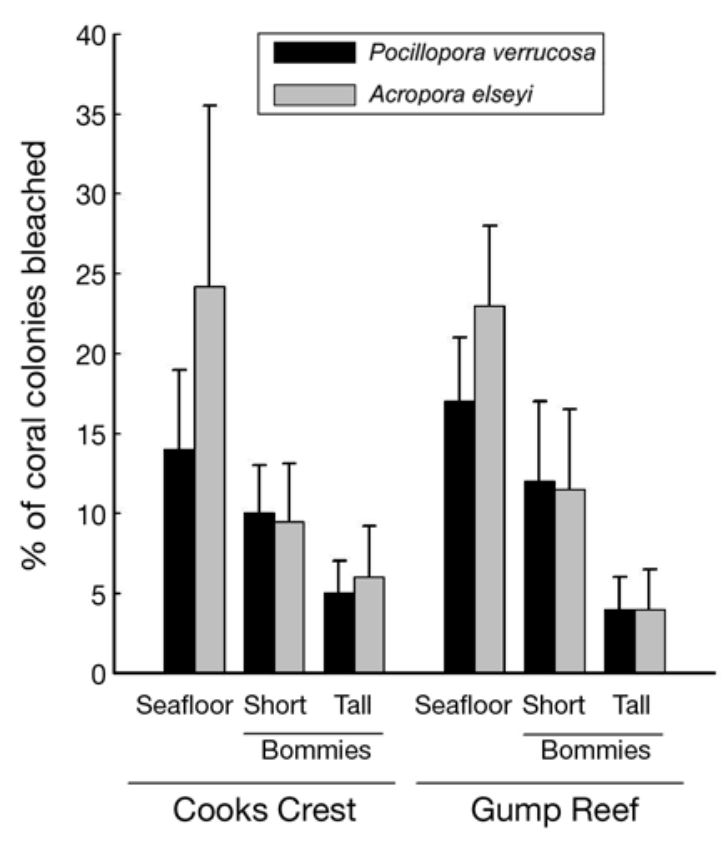

Fig. 3. Pocillopora verrucosa, Acropora elseyi. Mean ( \pm 1 SE) percent of naturally occurring, adult pocilloporid and acroporid coral colonies found bleached on the seafloor and short (30 to $45 \mathrm{~cm}$ tall) and tall (1 to $1.2 \mathrm{~m}$ tall) bommies at Cook's Crest and Gump Reef in Moorea, French Polynesia, on $19 \mathrm{Au}-$ gust 2003. A colony had to have $\geq 25 \%$ of the total area of tissue bleached to be considered a bleached coral. Data were collected along $20 \mathrm{~m}$ long $\times 2 \mathrm{~m}$ wide transects ( $\mathrm{N}=4$ per site). Totals of 23 to 83 corals of each family were counted along each transect

tive statistics for bleaching rates and environmental conditions (temperature, current speed, sedimentation, and light) in the experiment are displayed by reef structure in Table 3 . We present mean and standard deviations for each reef structure pooled across Cook's Crest and Gump Reef because results from the analyses of temperature (see above) and those from regression models for all variables (see below) displayed no statistically significant $(p>0.05)$ differences in environmental conditions between sites. The combined value for each variable in Table 3 is the mean for all reef structures combined. Mean percent bleaching for $P$. verrucosa and A. elseyi, measured on 20 August at

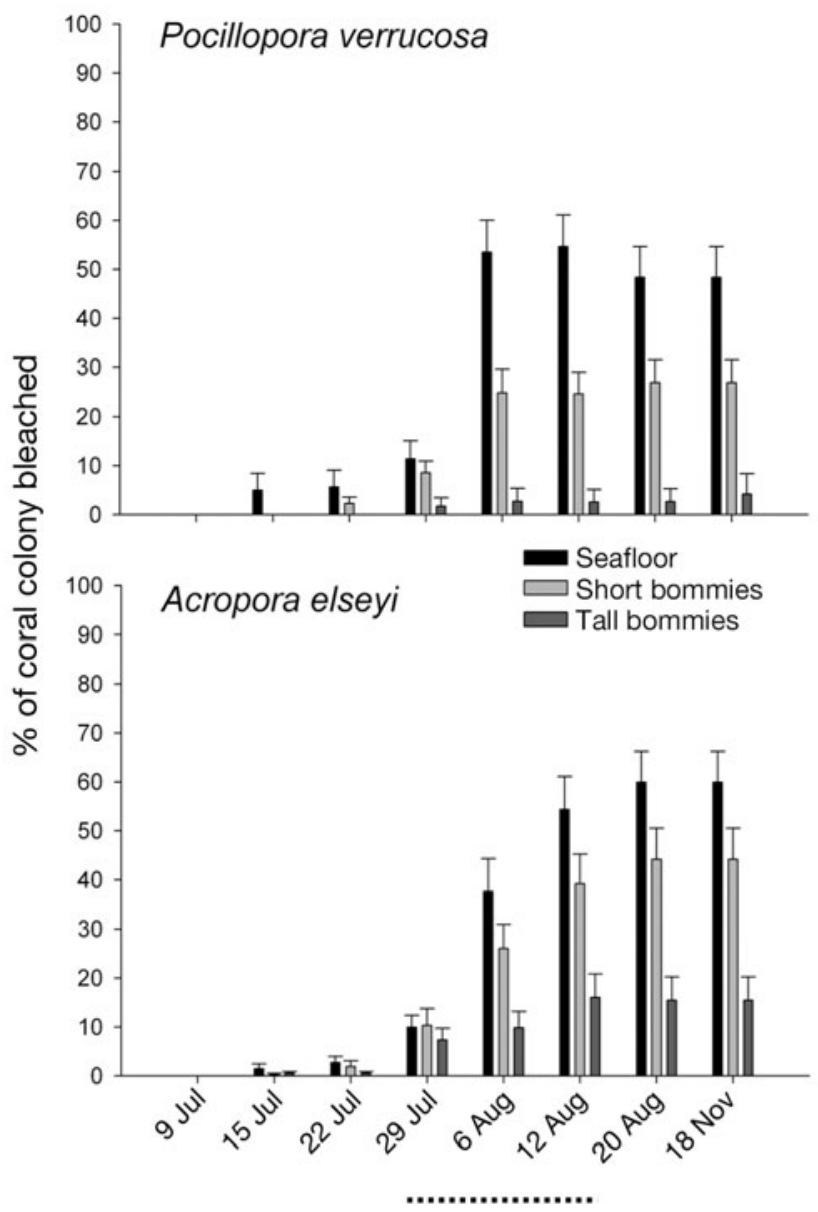

Fig. 4. Pocillopora verrucosa, Acropora elseyi. Mean ( \pm 1 SE) percent of tissue found bleached across replicate colonies through time on corals transplanted to different reef structures at Cook's Crest and Gump Reef. Data were pooled across the 2 sites because of a lack of statistical differences in percentage bleaching as a function of site (see 'Results'). Short bommies were 0.35 to $0.40 \mathrm{~m}$ tall and tall bommies were 1.0 to $1.2 \mathrm{~m}$ tall. Dashed line under the $\mathrm{x}$-axis represents when the warming period occurred

the peak of bleaching, declined with increasing distance above the seafloor (seafloor > short bommies > tall bommies). Mean current speed measured on the tops of reef structures increased with distance above the seafloor, as did light, which in contrast to current

Table 3. Means (and standard deviations) for bleaching and environmental measurements taken on the seafloor, and on short and tall bommies, as well those for all 3 reef structures combined

\begin{tabular}{|c|c|c|c|c|}
\hline Variable & Combined & Seafloor & Short & Tall \\
\hline Pocillopora verrucosa ( $\%$ tissue bleached colony ${ }^{-1}$ ) & $31.8(34.8)$ & $53.4(41.2)$ & $26.9(29.9)$ & $15.1(19.0)$ \\
\hline Acropora elseyi ( $\%$ tissue bleached colony $\left.{ }^{-1}\right)$ & $39.7(43.6)$ & $55.8(46.5)$ & $41.7(41.4)$ & $21.6(37.3)$ \\
\hline Current speed $\left(\mathrm{cm} \mathrm{s}^{-1}\right)$ & $6.88(4.12)$ & $3.26(2.41)$ & $6.43(1.71)$ & $10.95(3.55)$ \\
\hline Sedimentation $\left(\mathrm{g} \mathrm{cm}^{-2} \mathrm{~d}^{-1}\right)$ & $0.14(0.10)$ & $0.23(0.10)$ & $0.14(0.07)$ & $0.07(0.05)$ \\
\hline Light $\left(\mu \mathrm{mol} \mathrm{m} \mathrm{m}^{-2} \mathrm{~s}^{-1}\right)$ & $1608.8(219.4)$ & $1447.2(130.4)$ & $1623.1(152.8)$ & $1756.2(242.0)$ \\
\hline Temperature $\left({ }^{\circ} \mathrm{C}\right)$ & $28.8(0.3)$ & $28.8(0.3)$ & $28.8(0.2)$ & $28.83(0.2)$ \\
\hline
\end{tabular}




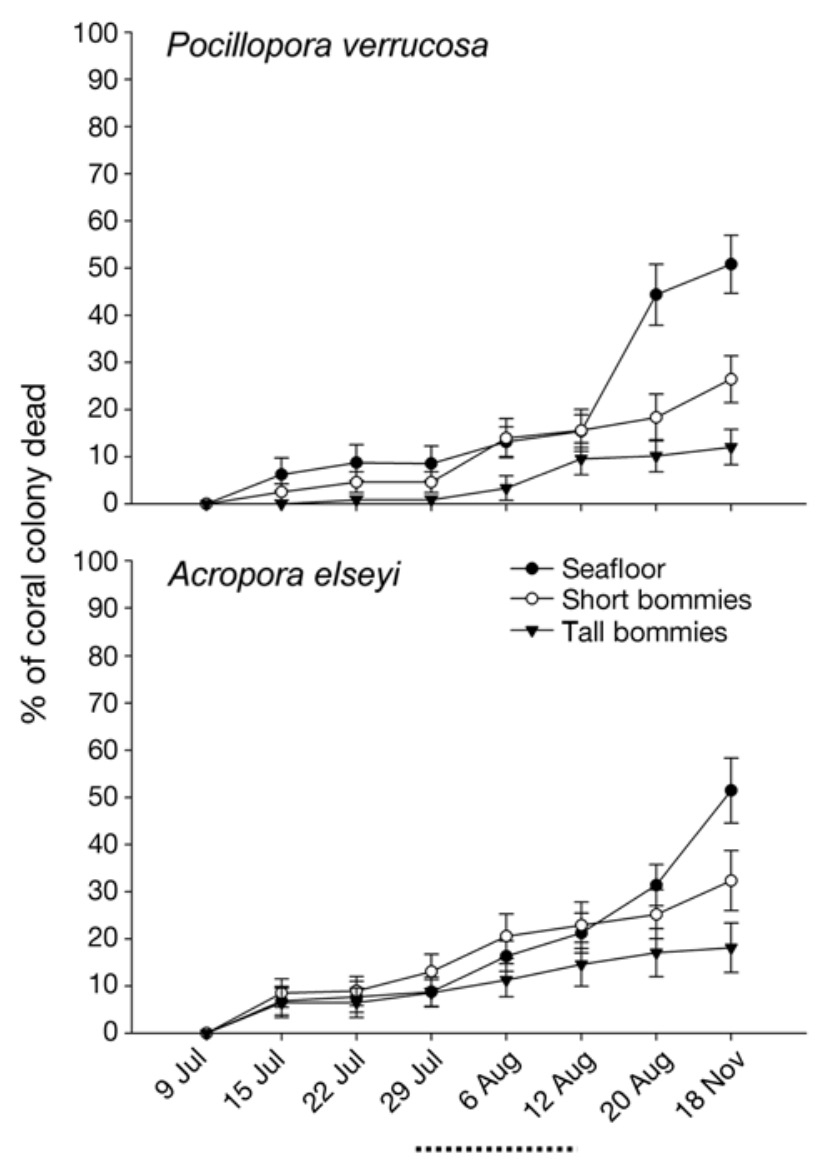

Fig. 5. Pocillopora verrucosa, Acropora elseyi. Mean ( \pm 1 SE) percent of tissue found dead across replicate colonies through time on corals transplanted to different reef structures at Cook's Crest and Gump Reef in Moorea. Dashed line under the $x$-axis represents when the warming period occurred. These are the same corals illustrated in Fig. 4

speed, showed relatively little difference across the structures. Mean sedimentation rate was fairly low across all structures $\left(<1 \mathrm{~g} \mathrm{~cm}^{-2} \mathrm{~d}^{-1}\right)$ but declined with distance above the bottom. Water temperature, measured during the warming event, changed very little across reef structures.

The estimates of regression equations (Eqs. 1 \& 2) are reported for Pocillopora verrucosa and Acropora elseyi in Table 4. As one would expect, Eq. (2) explains more of the variation in bleaching, with non-trivial increases in the $R$-squared statistics for both species. A test of the restriction that all interaction variables (between environmental conditions and reef structures; see Table 5) equal zero was strongly rejected for both $P$. verrucosa (regression: $\mathrm{df}=8,44 ; F=5.15$; $\mathrm{p}<$ 0.01 ) and $A$. elseyi (regression: $\mathrm{df}=8,44 ; F=2.61, \mathrm{p}=$ 0.02). The models explained more of the variation in bleaching for $P$. verrucosa compared with that of A. elseyi. Despite inclusion of the observed environ- mental conditions, the $P$. verrucosa models revealed the presence of some unobserved factor(s) that affected bleaching on tall bommies differently to both the seafloor and short bommies in Model 1 and to only short bommies in Model 2. A few patterns also emerge with respect to the effects of the environmental conditions, and we now focus on these results. Although not reported, we also estimated specifications that included interactions between the different environmental conditions. We do not report these results because none were statistically significant.

To facilitate comparisons, Table 5 reformats the regression results that relate to the effects of environmental conditions. Column a is simply a retype of the coefficient estimates of $\beta$ from Model 1 . We refer to these as the 'combined' estimates because they combine all the data in different reef structures to estimate a single effect of each environmental variable. Column $\mathrm{b}$ is simply a retype of the coefficient estimates of $\boldsymbol{\beta}$ from Model 2. As described above, these estimates are interpreted as the effects of environmental variables on bleaching on the seafloor. Columns $\mathrm{c}$ and $\mathrm{d}$ report the estimates of $\boldsymbol{\beta}+\boldsymbol{\varphi}$ and $\boldsymbol{\beta}+\boldsymbol{\phi}$, respectively, which are interpreted as the effects of environmental variables on bleaching on short and tall bommies. We report $t$-statistics for all estimates, along with $\mathrm{p}$-values in the last 3 columns for the hypothesis tests of equality between coefficients for each of the corresponding pairwise comparisons.

For Pocillopora verrucosa, we found that in the combined model an increase in mean current speed of $1 \mathrm{~cm}$ $\mathrm{s}^{-1}$ decreased bleaching by approximately $7 \%$. This is signified by the negative coefficients in 3 of the first 4 columns of Table 5. However, the combined estimate was less than the seafloor estimate of $19 \%$ and greater than the tall bommie estimate of $5 \%$, thus indicating that current speed had a substantially greater negative effect on bleaching on the seafloor than on the tops of tall bommies. Pair-wise comparisons revealed that the effect of current speed differed significantly between our 3 reef structures, but also showed that the effect on short bommies was not significantly different from zero.

We also found statistically significant results for the effect of sediment deposition $\left(\mathrm{g} \mathrm{cm}^{-2} \mathrm{~d}^{-1}\right)$ on bleaching in Pocillopora verrucosa. The positive coefficients indicate that sedimentation increased the amount of bleaching. The combined estimate implies that across all reefs an increase in $100 \mathrm{~g} \mathrm{~cm}^{-2} \mathrm{~d}^{-1}$ in sedimentation increased bleaching by approximately $1.7 \%$. This result is close to the reef-specific estimate of $1.3 \%$ for tall bommies, but it is substantially lower than the $5.2 \%$ estimate for short bommies. The estimate for the seafloor is not different from zero, with a reasonable degree of statistical significance. Therefore, sedimenta- 
Table 4. Pocillopora verrucosa, Acropora elseyi. Linear regression results to explain the percent of coral bleaching in the transplant experiment as a function of environmental conditions ('variables') measured on experimental reefs. (1) and (2) refer to Eqs. (1) and (2), respectively, given in 'Materials and methods: Statistical approach'. Values are regression coefficients and associated $t$-statistics (given in parentheses). The dependent variable is the percent of bleached coral. We rescaled units of sediment (multiplied by 100) and light (divided by 100) to simply report coefficients of comparable magnitudes. $t$-statistics are based on standard errors that are robust to heteroscedasticity; 3, 2, or 1 asterisks indicate statistical significance at the $\alpha=0.01$, 0.05 , and 0.10 levels, respectively

\begin{tabular}{|c|c|c|c|c|}
\hline \multirow[t]{2}{*}{ Variable } & \multicolumn{2}{|c|}{ Pocillopora verrucosa } & \multicolumn{2}{|c|}{ Acropora elseyi } \\
\hline & (1) & $(2)$ & $(1)$ & $(2)$ \\
\hline Current speed $\left(\mathrm{cm} \mathrm{s}^{-1}\right)$ & $-7.1(3.5)^{* * *}$ & $-18.8(4.9)^{* * *}$ & $-4.7(1.44)$ & $-14.0(2.7)^{* *}$ \\
\hline Sedimentation $\left(\mathrm{g} \mathrm{cm}^{-2} \mathrm{~d}^{-1}\right)$ & $1.68(2.13)^{* *}$ & $-0.21(0.19)$ & $1.21(1.05)$ & $0.31(0.19)$ \\
\hline Light $\left(\mu \mathrm{mol} \mathrm{m}{ }^{-2} \mathrm{~s}^{-1}\right)$ & $-2.49(1.23)$ & $-7.22(1.83)^{*}$ & $-0.56(0.19)$ & $6.87(1.38)$ \\
\hline Temperature $\left({ }^{\circ} \mathrm{C}\right)$ & $15.74(1.11)$ & $-30.79(1.52)$ & $0.07(0.00)$ & $-27.33(0.88)$ \\
\hline Flow $\times$ Short bommies & - & $27.7(4.1)^{* * *}$ & - & $4.3(0.4)$ \\
\hline Flow $\times$ Tall bommies & - & $13.8(3.7)^{* * *}$ & - & $11.6(2.2)^{* *}$ \\
\hline Sediment $\times$ Short & - & $5.43(2.45)$ & - & $1.26(0.38)$ \\
\hline Sediment $\times$ Tall & - & $1.49(1.20)$ & - & $-2.07(1.06)$ \\
\hline Light $\times$ Short & - & $4.50(0.78)$ & - & $-7.32(0.98)$ \\
\hline Light $\times$ Tall & - & $8.65(1.97)^{*}$ & - & $-4.14(0.65)$ \\
\hline Temperature $\times$ Short & - & $35.63(1.15)$ & - & $51.03(1.05)$ \\
\hline Temperature × Tall & - & $64.23(2.67)^{* *}$ & - & $56.14(1.19)$ \\
\hline Short & $15.48(1.02)$ & $-1308.16(1.52)$ & $12.55(0.74)$ & $-1375.51(0.98)$ \\
\hline Tall & $50.01(2.05)^{* *}$ & $-2038.95(2.93)^{* * *}$ & $22.71(0.67)$ & $-1601.52(1.16)$ \\
\hline Cook's Bay & $23.89(1.52)$ & $31.64(2.41)^{* *}$ & $6.43(0.28)$ & $16.56(0.69)$ \\
\hline Constant & $-391.08(0.94)$ & $1095.63(1.85)$ & $46.87(0.08)$ & $774.46(0.83)$ \\
\hline Test: Tall - Short $=0$ & $34.52(2.42)^{* *}$ & $-730.78(1.00)$ & $10.16(0.43)$ & $-226.01(0.15)$ \\
\hline$R$-squared & 0.44 & 0.64 & 0.23 & 0.35 \\
\hline
\end{tabular}

Table 5. Summary of the estimated effects of environmental conditions on coral bleaching in the transplant experiment. Values are regression coefficients and associated $t$-statistics. The $t$-statistics are given in parentheses and are based on standard errors that are robust to heteroscedasticity; 3,2 , or 1 asterisks indicate statistical significance of $t$-statistics at the $\alpha=0.01,0.05$, and 0.10 levels, respectively. Numbers in the last 3 columns are p-values for the hypothesis tests comparing equality between the variables in the corresponding columns

\begin{tabular}{|c|c|c|c|c|c|c|c|}
\hline \multirow[t]{2}{*}{ Variable } & \multirow[t]{2}{*}{ (a) Combined } & \multirow[t]{2}{*}{ (b) Seafloor } & \multirow[t]{2}{*}{ (c) Short } & \multirow[t]{2}{*}{ (d) Tall } & \multicolumn{3}{|c|}{ _ Hypothesis tests } \\
\hline & & & & & $\mathrm{b}=\mathrm{c}$ & $\mathrm{b}=\mathrm{d}$ & $\mathrm{c}=\mathrm{d}$ \\
\hline \multicolumn{8}{|c|}{ Pocillopora verrucosa } \\
\hline Current speed & $-7.1(3.50)^{* * *}$ & $-18.8(4.9)^{* * *}$ & $8.9(1.50)$ & $-5.1(2.40)^{* *}$ & 0.00 & 0.00 & 0.03 \\
\hline Sedimentation & $1.68(2.13)^{* *}$ & $-0.21(0.19)$ & $5.22(2.61)^{* *}$ & $1.29(2.06)^{* *}$ & 0.02 & 0.24 & 0.06 \\
\hline Light & $-2.49(1.23)$ & $-7.22(1.83)^{*}$ & $-2.72(0.66)$ & $1.43(0.72)$ & 0.44 & 0.06 & 0.38 \\
\hline Temperature & $15.74(1.10)$ & $-30.79(1.52)$ & $4.84(0.20)$ & $33.44(2.51)^{* *}$ & 1.26 & 0.01 & 0.29 \\
\hline \multicolumn{8}{|l|}{ Acropora elseyi } \\
\hline Current speed & $-4.7(1.4)$ & $-14.0(2.7)^{* *}$ & $-9.7(1.0)$ & $-2.4(0.5)$ & 0.7 & 0.03 & 0.5 \\
\hline Sedimentation & $1.21(1.05)$ & $0.31(0.19)$ & $1.58(0.50)$ & $-1.76(1.28)$ & 0.71 & 0.30 & 0.29 \\
\hline Light & $-0.56(0.19)$ & $6.87(1.38)$ & $-0.45(0.08)$ & $2.73(0.71)$ & 0.33 & 0.52 & 0.65 \\
\hline Temperature & $0.07(0.00)$ & $-27.33(0.88)$ & $23.7(0.63)$ & $28.81(0.79)$ & 0.30 & 0.24 & 0.92 \\
\hline
\end{tabular}

tion increased bleaching on short bommies to a greater degree than it did on the seafloor and tall bommies. However, these estimates are based on levels of sedimentation that were increased by a factor of 100 above the levels we measured in the field (see Table 3). Consequently, the actual effects of sediment deposition, although statistically significant, were actually quite small.

Results for the effects of light and temperature variation (during the warming event only) on bleaching in Pocillopora verrucosa were less robust (Table 5). We found that an increase in light of $100 \mu \mathrm{mol} \mathrm{s} \mathrm{s}^{-1} \mathrm{~m}^{-2}$ decreased bleaching by approximately $7 \%$ on the seafloor. Light also decreased bleaching on short bommies, but the trend was not statistically significant. In contrast, light increased bleaching on tall bommies, but again the trend was not statistically significant. The effect of temperature on bleaching differed between the seafloor and tall bommies. While the effect is not statistically different from zero on the seafloor, the relationship was positive and quite large on tall bommies, where an increase in temperature of $1^{\circ} \mathrm{C}$ increased the extent of bleaching by approximate $33 \%$, a result that differed from zero (at $\alpha=0.05$ ). 
We found only 2 results with statistical significance for Acropora elseyi. Mirroring that for Pocillopora verrucosa, current speed decreased the extent of bleaching on the seafloor and had less of a negative effect on bleaching intensity on tall bommies. The magnitude was also similar to that for $P$. verrucosa, as a $1 \mathrm{~cm} \mathrm{~s}^{-1}$ increase in current speed decreased bleaching on the seafloor by approximately $14 \%$, but decreased bleaching by only $2 \%$ on tall bommies. In contrast to results for $P$. verrucosa, the same increment of current decreased bleaching in A. elseyi by $9 \%$ on short bommies. Despite the relatively limited results for $A$. elseyi that are statistically significant, it is worth noting that the patterns of results between the 2 species were quite similar. The sign of the estimated coefficients in the combined models and reefspecific models were suggestive of 2 general tendencies: increases in current speed decreased bleaching and bleaching increased with sedimentation. With respect to temperature and light, however, the patterns are less clear.

\section{Acclimation in transplanted corals}

On 19 and 20 August, when coral bleaching reached its highest level, there was no difference in the percentage of bleaching of Pocillopora verrucosa between the reciprocal controls and experimental transplants located on the seafloor at Gump Reef (1-way ANOVA: $\mathrm{df}=1,35 ; \mathrm{MS}=0.44 ; F=0.03 ; \mathrm{p}=0.86)$ or Cook's Crest (1-way ANOVA: df $=1,31 ; \mathrm{MS}=0.28 ; F=0.02 ; \mathrm{p}=$ 0.89). The same pattern was observed for Acropora elseyi at Gump Reef (1-way ANOVA: df = 1,35; $\mathrm{MS}=$ 11.11; $F=0.30 ; \mathrm{p}=0.58$ ) and Cook's Crest (1-way ANOVA: $\mathrm{df}=1,31 ; \mathrm{MS}=49.85 ; F=1.57 ; \mathrm{p}=0.22$ ). Transplanted corals also bleached at higher rates than naturally occurring corals, a result we expected because (1) all transplants were subjected to some stress associated with the transplantation process and (2) naturally occurring corals were much larger, and, therefore, we reason, more resilient to bleaching (Brown 1997). Results of the comparisons between all pairs of transplant combinations in the experiment (e.g. corals at Position A transplanted to Position $C_{i}$ Fig. 2) revealed no evidence suggesting that enhanced bleaching on the seafloor was caused by variation in the acclimation of coral transplants to new environments (Table A1, available at http://www.int-res.com/ articles/suppl/m370p127_app.pdf). Results of comparisons in the transplant controls revealed once again that the only corals that bleached were those predicted by the reef structure effect (Table A2, available at http://www.int-res.com/articles/suppl/m370p127_app. pdf). Together, this is strong evidence (1) suggesting that our transplanting process did not bias our results and (2) supporting the idea that corals may acclimate to new environmental conditions within several weeks (sensu van Woesik et al. 2005).

\section{Mortality of bleached corals}

On 19 November, long after the warming event, mortality in the transplanted corals was much higher for bleached corals than for unbleached corals (Fig. 5). Mortality in Pocillopora verrucosa was higher on the seafloor than on short and tall bommies (1-way ANOVA: $\mathrm{df}=2,119 ; \mathrm{MS}=15370.0 ; F=14.78 ; \mathrm{p}<$ 0.0001; SNKs: $p<0.05)$. There was no difference in mortality between the short and tall bommies (SNK: $\mathrm{p}>0.05)$. The same pattern was observed for Acropora elseyi (1-way ANOVA: df =2,119; $\mathrm{MS}=22337.9 ; F=$ 7.15; $\mathrm{p}=0.001$; SNKs: $\mathrm{p}<0.05)$.

\section{DISCUSSION}

\section{Ecological significance}

A period of very low wave energy in the ocean led to reduced flushing by cooler ocean water and almost complete cessation of circulation within lagoons of Moorea from July to August 2003. In turn, a relatively large increase in lagoon water temperature led to the bleaching of lagoon corals. Our results show that bleaching in naturally occurring Pocillopora spp. and Acropora spp. colonies, as well as transplanted $P$. verrucosa and $A$. elseyi, varied substantially with reef structure, at a length scale of centimeters to meters. At replicate sites, located several kilometers apart, corals positioned on the tops of short bommies ( 0.40 to $0.45 \mathrm{~m}$ tall) and tall bommies (1 to $1.2 \mathrm{~m}$ tall) bleached at lower rates than corals located on the seafloor. There was also a trend towards greater bleaching on short bommies than on tall bommies, but the difference between the 2 positions was not statistically significant (see Fig. 4). Differences in bleaching across the reef structures were significantly correlated with differences in current speed and sedimentation and, to a lesser degree, with light and temperature. Our results imply that the physical structure of a reef, especially its height, influences local environmental conditions, which, in turn, regulate the pattern of bleaching in corals.

Regression analysis of our transplant experiment showed that bleaching in Pocillopora verrucosa was negatively correlated with current speed on tall bommies, indicating that ambient flow at this position is associated with reduced bleaching. Current speed also had a strong negative effect on bleaching of $P$. verru- 
cosa on the seafloor, implying that bleaching would have been much greater at this position had ambient current speed been lower. A very similar relationship between reef structure, current speed, and bleaching was observed for Acropora elseyi. Sedimentation was positively correlated with bleaching in $P$. verrucosa on short and tall bommies, indicating that sediment deposition enhanced bleaching at these 2 positions. Bleaching in $P$. verrucosa was also negatively correlated with light levels on the seafloor, implying that increasing light levels at this position can reduce bleaching. Temperature was positively correlated with bleaching in $P$. verrucosa on tall bommies, indicating that relatively small differences in temperatures occurring during a warming event can influence bleaching at this position independently of current speed, sedimentation, and light. Although there were no statistically significant relationships between sedimentation, light, or temperature and bleaching in $A$. elseyi, the patterns were qualitatively similar to those for $P$. verrucosa.

How water movement influences coral bleaching has been hotly debated (McClanahan et al. 2005b, van Woesik et al. 2005). The hypothesis that increased current speed reduces bleaching has been supported by field observations (Loya et al. 2001, Nakamura \& van Woesik 2001, Fabricius 2006) and numerous laboratory experiments (Nakamura et al. 2003, 2005, Nakamura \& Yamasaki 2005, Fabricius 2006, Finelli et al. 2006, Smith \& Birkeland 2007). Here we provide, to our knowledge, the first manipulative field experimental evidence that supports the hypothesis that flow decreases bleaching and related mortality.

Water movement is thought to reduce bleaching and enhance recovery because it (1) increases the mass transfer of material across the tissue-water interface, thus reducing photoinhibition caused by the in vivo build up in concentrations of toxic compounds (Lesser 1997, Nakamura et al. 2005, Finelli et al. 2006); (2) enhances primary production, respiration, metabolism, and food capture, thus increasing energy supply and the physiological condition of corals (Lesser et al. 1990, Sebens et al. 2003); and (3) can replace comparatively warm water immediately surrounding dark-colored coral colonies (Fabricius 2006). Recent work by Anthony et al. (2007) showed that food material associated with suspended sediment provides energy to corals that can increase their capacity to recover from bleaching. In contrast, McClanahan et al. (2005a) reported results of field observations indicating that current speed was positively correlated with bleaching. They reasoned that periodic exposure to low flow produces corals adapted to stressful temperatures, especially in closed lagoons with restricted circulation (Castillo \& Helmuth 2005, McClanahan et al. 2005b). McClanahan et al. (2005b) also argued that the posi- tive influence of flow on bleaching has usually been observed under controlled laboratory conditions that do not reflect the highly variable environmental conditions observed in field studies. Our study is a valuable contribution to this on-going debate because our manipulative field experiment was the first direct test of the separate and combined effects on bleaching of a subset of relevant environmental conditions, including flow.

Our work supports the hypothesis that current speed can reduce the level of bleaching under natural conditions, at least for 2 of 3 species that we examined. Flow before and after the bleaching event apparently reduced bleaching, as there was very little flow during the bleaching event. Corals in higher current speeds prior to the bleaching event may have been in better physiological condition and therefore more resilient than corals in relatively low current speeds (Nakamura \& Yamasaki 2005). In addition, or alternatively, the resumption of flow after the bleaching event may have limited further bleaching by enhancing mass transfer and localized cooling that, in turn, increased tissue recovery from bleaching, especially in Pocillopora verrucosa (see Fig. 4; Nakamura et al. 2005). We also show that sedimentation, which can co-vary with water movement, also influences bleaching intensity, as does light availability, which can reduce bleaching intensity at positions such as the seafloor between bommies, where periodic shading may limit and therefore improve coral performance. Together these patterns indicate that the physical structure of coral reefs, especially their topographic complexity, can influence environmental conditions with subsequent effects on the small-scale spatial pattern of coral bleaching.

McClanahan et al. (2005b) also criticized bleaching experiments that use coral transplants not given sufficient time to acclimatize to conditions at a transplant site, and that do not include truly reciprocal transfers of corals between sites. These criticisms were questioned in part by van Woesik et al. (2005), who pointed out that several studies (e.g. Lesser et al. 1994, Anthony \& Hoegh-Guldberg 2003) have shown corals can acclimatize to a new site in only a few weeks when they develop stress-tolerant zooxanthella communities. Corals in our experiment were situated on our reef treatments from 28 to $195 \mathrm{~d}$ before the bleaching event and showed no apparent signs of bleaching due to the transplantation process. Nevertheless, we agree with McClanahan et al. (2005b) that iterative field studies are needed and that a next logical step is to compare bleaching responses of different genets, as well as taxa, in fully reciprocal transplant experiments that control for the effects of microhabitat structure and environmental variables, including current speed. 
Variation in bleaching susceptibility among coral taxa may be an important factor in the emergence of reefs dominated by massive corals, such as Porites spp. (e.g. Gleason 1993). We found that Acropora elseyi and Pocillopora verrucosa readily bleached in our experiment (in low flow conditions), but Porites rus did not bleach or die under any conditions. Sampling conducted in November 2004, 1 yr after our experiment, showed that $87 \%$ of the transplanted $P$. rus colonies survived, while only $62 \%$ of the $A$. elseyi and $58 \%$ of the $P$. verrucosa survived. Several theories have been proposed to explain why poritids are more tolerant to bleaching than other taxa, including some acroporids and pocilloporids (Loya et al. 2001, Coles \& Brown 2003). The basis for most of these theories is that some coral taxa, or their zooxanthellae, have a higher capacity to acclimate and adapt to elevated temperature and light levels than other species. The taxonomic difference in bleaching susceptibility and subsequent mortality that we observed may help to explain why communities of corals in Moorean lagoons have shifted from those dominated mainly by branching acroporids to those dominated by massive poritids (Done et al. 1991). Whether repeated bleaching events in Moorea are also related to the emergence of pocilloporids as a dominant family is less clear (Adjeroud et al. 2005, Berumen \& Pratchett 2006). Populations of pocilloporids may be responding better than acroporids to repeated bleaching events and other natural catastrophes, including storms and outbreaks of crownof-thorns starfish, because pocilloporids have opportunistic life-history characteristics that allow them to more rapidly recolonize available substrate (Ayre et al. 1997).

\section{Relevance to coral reef conservation}

Coral reefs have been degraded and destroyed by human activities in many regions (Hodgson 1999, Wilkinson 2002, Hughes et al. 2003). As a result, greater attention is being paid to coral reef conservation and restoration (Grigg 1994, Thomas 2001, Miller 2002, Aronson \& Precht 2006, Bell et al. 2006). How do the results of our experiment inform conservation strategies and practices? A common objective in reef conservation is to reduce anthropogenic disturbances and allow the natural recovery of corals to proceed, sometimes by reducing human interference through establishment of marine reserves (Fernandes et al. 2005, Kareiva 2006). West \& Salm (2003) distinguished a set of environmental features of reef habitat that are correlated with coral resistance and resilience to bleaching. Based on a synthesis of information from the literature and field surveys, they argued that reefs that were shaded or were exposed to relatively high water movement should be primary targets for conservation and reserve establishment. In addition, Anthony \& Kerswell (2007) found that corals in areas exposed to waves bleached less than those in wave-protected areas, especially because waves can reduce desiccation stress during extremely low tides. Results of our experiment support predictions generated in these studies, but also indicate that differences in the physical structure of habitat within a single patch of reef, at relatively small spatial scales, should be incorporated in conservation models. For example, site selection for conservation areas or reserves could incorporate information on the topographic complexity of reef habitat, including the presence of reef bommies created by massive corals. In areas where reserve establishment is possible but high quality reefs (e.g. those with shading, high current speed, and low sedimentation) or massive corals are unavailable, conservation plans might include the introduction of natural or artificial reef bommies, if such an undertaking were practical and cost effective. In general, it is unlikely that a large proportion of the world's coral reefs will be protected in reserves (Ault et al. 2005), so more effective management of processes that degrade reefs, such as terrestrial sediment input, reduced water quality, and destructive fishing practices, are imperative. Another management strategy to consider is maintaining or even enhancing circulation in lagoons, which can be adversely affected by dredging activities, channel realignments, and breakwaters.

A well-appreciated ecological function of coral reefs is the maintenance of biodiversity. A related conservation objective is the protection of complex reef structure based on the ecological principal that reef structural complexity begets species diversity (Munday et al. 1997, Jones et al. 2004). Emphasis is therefore often placed on preserving acroporids, pocilloporids, and other branching corals because they provide physically complex reef habitat for other species. Our results imply that to promote communities with abundant populations of Acopora spp. and Pocillopora spp., we should maintain an underlying framework of reef habitat that enhances abiotic conditions, such as water movement, that have positive impacts on preferred coral species. Consequently, when selecting of areas to protect one should consider topographic complexity and inherent coral species diversity because both characteristics apparently represent the community type with the most resilience to environmental stress. Results of our study suggest that coral reef conservation would benefit from more careful consideration of the mechanisms by which reef structure controls local environmental conditions and reduces environmental stress. 
Acknowledgements. We thank A. Greenely, O. Lenihan, K. Nichols, T. Yousing, S. Palumbi, and A. Yau for help in the field and laboratory. S. Holbrook, R. Schmitt, R. Galzin, and Rita Yousing provided logistical support in Moorea. Y. Chancerelle provided temperature data from Tiahura. H. Stewart, A. Hadley, M. Kay, C. Peterson, and 3 anonymous reviewers helped improve the manuscript. This study was supported through the Moorea Coral Reef LTER (NSF Grant No. OCE0417412), BioAqua (Délégation à la Recherche de la Polynésie française, DRRT, ANR) for M.A., and NSF Grant OCE-0622967 to J.L.H. T.N. thanks the 21st COE program of University of the Ryukyus and Grant-in-Aid for the JSPS fellow. This is Contribution No. 172 from the University of California, Berkeley's Richard Gump Research Station in Moorea, French Polynesia.

\section{LITERATURE CITED}

Adjeroud M (1997) Factors influencing spatial patterns on coral reefs around Moorea, French Polynesia. Mar Ecol Prog Ser 159:105-119

> Adjeroud M, Augustin D, Galzin R, Salvat B (2002) Natural disturbances and interannual variability of coral reef communities on the outer slope of Tiahura (Moorea, French Polynesia):1991 to 1997. Mar Ecol Prog Ser 237:121-131

Adjeroud M, Chancerelle Y, Schrimm M, Perez T, Lecchini D, Galzin R, Salvat B (2005) Detecting the effects of natural disturbances on coral assemblages in French Polynesia: a decade long survey at multiple scales. Aquat Living Resour 18:111-123

Anthony KRN, Hoegh-Guldberg O (2003) Kinetics of photoacclimation in corals. Oecologia 134:23-31

Anthony KRN, Kerswell AP (2007) Coral mortality following extreme low tides and high solar radiation. Mar Biol 151: 1623-1631

Anthony KRN, Connelly SR, Hoegh-Guldberg O (2007) Bleaching, energetics, and coral mortality risk: effects of temperature, light, and sedimentary regime. Limnol Oceanogr 52:716-726

Aronson RB, Precht WF (2006) Conservation, precaution, and Caribbean reefs. Coral Reefs 25:441-450

Ault JS, Bohnsack JA, Smith SG, Luo LG (2005) Towards sustainable multispecies fisheries in the Florida, USA, coral reef ecosystem. Bull Mar Sci 76:595-622

> Ayre DJ, Hughes TP, Standish RS (1997) Genetic differentiation, reproductive mode, and gene flow in the brooding coral Pocillopora damicornis along the Great Barrier Reef, Australia. Mar Ecol Prog Ser 159:175-187

Baker AC, Starger CJ, McClanahan TR, Glynn PW (2004) Corals adaptive response to climate change. Nature 430: 741

Bell JD, Ratner BD, Stobutzki I, Oliver JK (2006) Addressing the coral reef crisis in developing countries. Ocean Coast Manage 49:976-985

Berkelmans R (2002) Time-integrated thermal bleaching thresholds of reefs and their variation on the Great Barrier Reef. Mar Ecol Prog Ser 229:73-82

Berkelmans R, Oliver JK (1999) Large-scale bleaching of corals on the Great Barrier Reef. Coral Reefs 18:55-60

Berkelmans R, De'ath G, Kininmonth S, Skirving WJ (2004) A comparison of the 1998 and 2002 coral bleaching event on the Great Barrier Reef: spatial correlation, patterns and predictions. Coral Reefs 23:74-83

Berumen ML, Pratchett MS (2006) Recovery without resilience: persistent disturbance and long-term shifts in the structure of fish and coral communities at Tiahura Reef,
Moorea. Coral Reefs 25:647-653

Brown BE (1997) Adaptations of reef corals to physical environmental stress. Adv Mar Biol 31:221-299

Brown BE, Dunne RP, Goodson MS, Douglas AE (2002) Experience shapes the susceptibility of reef coral to bleaching. Coral Reefs 21:119-126

Castillo KD, Helmuth BST (2005) Influence of thermal history on the response of Montastraea annularis to short-term temperature exposure. Mar Biol 148:261-270

Coles SL, Brown BE (2003) Coral bleaching: capacity for acclimatization and adaptation. Adv Mar Biol 46:183-223

Connell JH, Hughes TP, Wallace CC (1997) A 30-year study of coral abundance, recruitment, and disturbance at several scales in space and time. Ecol Monogr 67:461-488

> Dayton PK (1971) Competition, disturbance, and community organization: the provision and subsequent utilization of space in a rocky intertidal community. Ecol Monogr 41: 351-389

Done TJ, Dayton PK, Dayton AE, Steger R (1991) Regional and local variability in recovery of shallow coral communities-Moorea, French Polynesia and the central Great Barrier Reef. Coral Reefs 9:183-192

Fabricius KE (2006) Effects of irradiance, flow, and colony pigmentation on the temperature microenvironment around corals: Implications for coral bleaching? Limnol Oceanogr 51:30-37

> Fernandes L, Day J, Lewis A, Slegers S and others (2005) Establishing representative no-take areas in the Great Barrier Reef: large-scale implementation of theory on marine protected areas. Conserv Biol 19:1733-1744

> Finelli CM, Helmuth BST, Pentcheff ND, Wethey DS (2006) Water flow influences oxygen transport and photosynthetic efficiency in corals. Coral Reefs 25:47-57

Fitt WK, Warner ME (1995) Bleaching patterns in four species of Caribbean corals. Biol Bull 189:298-307

> Fox HE, Caldwell RL (2006) Recovery from blast fishing on coral reefs: a tale of two scales. Ecol Appl 16:1631-1635

> Genin A, Dayton PK, Lonsdale PF, Spiess FN (1986) Corals on seamounts: evidence of current acceleration over deepsea topography. Nature 322:59-61

Gleason MG (1993) Effects of disturbance on coral communities: bleaching in Moorea, French Polynesia. Coral Reefs 12:193-201

Glynn PW (1993) Coral reef bleaching: ecological perspectives. Coral Reefs 12:1-17

Glynn PW (1996) Coral bleaching: facts, hypotheses, and implications. Glob Change Biol 2:495-509

Grigg RW (1994) The international coral reef initiative: conservation and effective management of marine resources. Coral Reefs 13:197-198

Hodgson G (1999) A global assessment of human effects on coral reefs. Mar Pollut Bull 38:345-355

Hoegh-Guldberg O (1999) Climate change, coral bleaching and the future of the world's coral reefs. Mar Freshw Res 50:839-866

Hoegh-Guldberg O, Salvat B (1995) Periodic mass-bleaching and elevated sea temperatures: bleaching of outer reef slope communities in Moorea, French Polynesia. Mar Ecol Prog Ser 121:181-190

Holbrook SJ, Schmitt RS, Brooks AJ (2002) Variation in structural attributes of patch-forming corals and in patterns of abundance of associated fishes. Mar Freshw Res 53: $1045-1053$

Huffacker CB (1958) Experimental studies on predation: dispersion factors and predator-prey oscillations. Hilgardia 27:343-383

Hughes TP (1994) Catastrophes, phase shifts, and large-scale 
degradation of a Caribbean coral reefs. Science 265: $1547-1551$

Hughes TP, Baird AH, Bellwood DR, Card M and others (2003) Climate change, human impacts, and the resilience of coral reefs. Science 301:929-933

> Jackson JBC, Kirby MX, Berger WH, Bjorndal KA and others (2001) Historical overfishing and the collapse of marine ecosystems. Science 293:629-638

Jokiel P, Perriss S, Seaton G, Rohozinski J (1997) UV-absorbing compounds in the coral Pocillopora damicornis: interactive effects of UV radiation, photosynthetically active radiation, and water flow. Limnol Oceanogr 42: 1468-1473

Jones GP, McCormik MI, Srinivasan M, Eagle JV (2004) Coral decline threatens fish biodiversity in marine reserves. Proc Natl Acad Sci USA 101:8251-8253

Kareiva P (2006) Conservation biology: beyond marine protected areas. Curr Biol 16:R533-R535

Kinzie RA, Takayama M, Santos SR, Coffroth MA (2001) The adaptive bleaching hypothesis: experimental tests of critical assumptions. Biol Bull 200:51-58

Lang JC, Wicklund RI, Dill RF (1988) Depth- and habitatrelated bleaching of reef corals near Lee Stocking Island, Bahamas. In: Choat JH et al. (eds) Proc 6th Int Coral Reef Symp. Symposium Executive Committee, Townsville, p 269-274

Lenihan HS (1999) Physical-biological coupling on oyster reefs: how habitat form influences individual performance. Ecol Monogr 69:251-275

> Lesser MP (1997) Oxidative stress causes coral bleaching during exposure to elevated temperature. Coral Reefs 16: 187-192

- Lesser MP, Stochaj WR, Tapely DW, Shick JM (1990) Bleaching in coral reef anthozoans: effects of irradiance, ultraviolet radiation, and temperature on the activities of protective enzymes against active oxygen. Coral Reefs 8: $225-232$

Lesser MP, Weis VM, Patterson MR, Jokiel JP (1994) Effects of morphology and water motion on carbon delivery and productivity in the reef coral Pocillopora damicornis (Linneaeus): diffusion barriers, inorganic carbon limitation, and biochemical plasticity. J Exp Mar Biol Ecol 178: 153-179

- Loya Y, Sakai K, Yamazato K, Nakano Y, Sambali H, van Woesik RT (2001) Coral bleaching: the winners and the losers. Ecol Lett 4:122-131

MacArthur RH, MacArthur JW (1961) On bird species diversity. Ecology 42:594-599

McClanahan TR, Miana J, Moothien-Pillay R, Baker AC (2005a) Effects of geography, taxa, water flow, and temperature on coral bleaching intensity in Mauritius. Mar Ecol Prog Ser 298:131-142

> McClanahan TR, Baker AC, Ateweberhan M, Miana J, Moothien-Pillay R (2005b) Refining coral bleaching experiments and models through reiterative field studies. Mar Ecol Prog Ser 305:301-303

> McWilliams JP, Côté IM, Gill JA, Sutherland WJ, Watkinsona AR (2005) Accelerating impacts of temperature-induced coral bleaching in the Caribbean. Ecology 86:2055-2060

Miller MW (2002) Using ecological processes to advance artificial reef goals. ICES J Mar Sci 59:S27-S31

> Mills MM, Sebens KP (2004) Ingestion and assimilation of nitrogen from benthic sediments by three species of coral. Mar Biol 145:1097-1106

Mumby PJ, Chisholm JRM, Edwards AJ, Andrefouet S, Jaubert J (2001) Cloudy weather may have saved Society Island reef corals during the 1998 ENSO event. Mar Ecol
Prog Ser 222:209-216

> Munday PL, Jones GP, Caley MJ (1997) Habitat specialization and the distribution and abundance of coral-dwelling gobies. Mar Ecol Prog Ser 152:227-239

> Nakamura T, van Woesik RT (2001) Water-flow rates and passive diffusion partially explain differential survival of corals during the 1998 bleaching event. Mar Ecol Prog Ser 212:301-304

Nakamura T, Yamasaki H (2005) Requirement of water-flow for sustainable growth of pocilloporid corals during high temperature periods. Mar Pollut Bull 50:1115-1120

> Nakamura T, Yamasaki H, van Woesik RT (2003) Water flow facilitates recovery from bleaching in the coral Stylophora pistillata. Mar Ecol Prog Ser 256:287-291

Nakamura T, van Woesik RT, Yamasaki H (2005) Photoinhibition is reduced by water flow in the reef-building coral Acropora digitifera. Mar Ecol Prog Ser 301:109-118

$>$ Obura DO (2005) Resilience and climate change: lessons from coral reefs and bleaching in the western Indian Ocean. Estuar Coast Shelf Sci 63:353-372

> Penin LM, Adjeroud M, Schrimm M, Lenihan HS (2007) High spatial variability in coral bleaching around Moorea (French Polynesia): patterns across reefs, locations, and water depths. CR Biol 330:171-181

> Rogers CS (1990) Responses of coral reefs and reef organisms to sedimentation. Mar Ecol Prog Ser 62:185-202

Rowan R, Knowlton N, Baker A, Jara J (1997) Landscape ecology of algal symbionts creates variation in episodes of coral bleaching. Nature 388:265-269

Sebens KP, Grace SP, Helmuth BST, Maney EJ, Miles SJ (1998) Water flow and prey capture by three scleractinian corals, Madracis mirabilis, Montastrea caevrnosa, and Porites porties, in a field enclosure. Mar Biol 131:347-360

Sebens KP, Helmuth BST, Carrington E, Agius B (2003) Effects of water flow on growth and energetics of the scleractinian coral Agaricia tenuifolia in Belize. Coral Reefs 22:35-47

Smith LW, Birkeland C (2007) Effects of intermittent flow and irradiance level on back reef Porites corals at elevated seawater temperature. J Exp Mar Biol Ecol 341:282-294

> Sotka EE, Thacker RW (2005) Do some corals like it hot? Trends Ecol Evol 20:59-62

Thomas JD (2001) Preface. In: Proceedings of the international conference on scientific aspects of coral reef assessment, monitoring, and restoration. Bull Mar Sci 69: 293-294

Thomas FIM, Atkinson MJ (1997) Ammonium uptake by coral reefs: effects of water velocity and surface roughness on mass transfer. Limnol Oceanogr 42:81-88

Underwood AJ, Denley EJ (1984) Paradigms, explanations, and generalizations about models for the structure of intertidal communities on rocky shores. In: Strong DR, Abele L, Simberloff D (eds) Ecological communities: conceptual issues and the evidence. Princeton University Press, Cambridge, MA, p 151-180

> van Woesik RT, Nakamura T, Yamaski H, Sheppard C (2005) Comment on 'Effects of geography, taxa, water flow, and temperature on coral bleaching intensity in Mauritius' (McClanahan et al. 2005). Mar Ecol Prog Ser 305:297-299

West JM, Salm RV (2003) Resistance and resilience to coral bleaching: implications for coral reef conservation and management. Conserv Biol 17:956-967

Wilkinson CR (2002) Status of coral reefs of the world. Australian Institute of Marine Science, Townsville

Yahel R, Yahel G, Genin A (2002) Daily cycles of suspended sand at coral reefs: a biological control. Limnol Oceanogr 47:1071-1083

Submitted: October 10, 2007; Accepted: July 8, 2008

Proofs received from author(s): October 18, 2008 